\title{
THE JOURNAL OF NAVIGATION
}

Volume 29

1976

PUBLISHED UNDER THE AUTHORITY OF THE COUNCIL EDITED BY M. W. RICHEY

THE ROYAL INSTITUTE OF NAVIGATION AT THE ROYAL GEOGRAPHICAL SOCIETY I KENSINGTON GORE, LONDON SW, $2 \mathrm{AT}$ SCOTTISH ACADEMIC PRESS LTD., 33 MONTGOMERY STREET, EDINBURGH EH7 $5 \mathrm{JX}$ 


\title{
THE ROYAL INSTITUTE OF NAVIGATION
}

\author{
PATRON
}

H.R.H. THE PRINCE PHILIP DUKE OF EDINBURGH, x.G., k.T., o.M.

\section{OFFICERS AND COUNCIL $1975-76$}

\author{
PRESIDENT \\ Sir Edward Fennessy, c.B.E. \\ VICE-PRESIDENTS \\ Captain B. J. Calvert \\ Mrs. Mary Pera \\ HONORARY TREASURER \\ Lieut.-Cmdr. R. B. Richardson, R.N. (Ret.) \\ CHAIRMAN OF THE TECHNICAL COMMITTEE \\ Captain R. Maybourn
}

CHAIRMAN OF THE MEMBERSHIP AND FELLOWSHIP COMMITTEE

Captain C. H. Cotter

MEMBERS OF COUNCIL

Prof. A. N. Black Group Captain H. L. Sheppard, R.A.F.

Rear Admiral D. W. Haslam, F. S. Stringer

O.B.E.

Captain R. J. Turner

A. H. Jessell .

Captain A. J. R. Tyrrell

Dr. J. F. Kemp

Lieut.-Cmdr. D. W. Waters, R.N.

S. Ratcliffe

DIRECTOR

M. W. Richey, M.B.E. 


\section{CONTENTS}

THE PRESIDENTIAL ADDRESS: NAVIGATION AND TECHNOLOGY. G. E. BECK NAUTICAL ASTRONOMY AND THE MERCATOR PRINCIPLE. C. H. CoTTER ROUTE FINDING BY DESERT ABORIGINES IN AUSTRALIA. D. LEWIS · MANCEUVRES IN FOG COMPATIBLE WITH THE COLLISION REGULATIONS

O. I. Mitrofanov.

THE COURSE OF NAVIGATION D J IINDSAY NAYIGATION FOR THE FISHING INDUSTRY G. HAINES $\cdot \cdot \cdot \cdot \cdot \cdot{ }^{\prime} \cdot{ }^{\prime}$ ON ERROR DISTRIBUTIONS IN NAVIGATION. O. D. ANDERSON . . 69 MISALIGNMENT ANGLE AND CALIBRATION OF A TWO-COMPONENT ELECTROMAGNETIC LOG. M. J. R. FASHAM . AN AUTOMATED INTEGRATED SHIP'S BRIDGE LAYOUT. C. ABraMowsKi . RATE AND RATIO IN RADAR COLLISION AVOIDANCE (Forum). J. VENDRELL EDUCATION AND THE SEA (Forum). L. W. J. FifieLd .

AUTOMATIC RADAR PLOTTING SYSTEMS (Forum). F. J. WYLIE . MULTIPLE SUN SIGHTS WITH ONE REDUCTION (ForUm). J. P. BUDLONG . FURTHER COMMENTS ON THE CALCULATION OF POSITION LINE DATA WITH A COMPUTER CALCULATOR (Forum). J. A. READ $\quad$. $\quad$ • 97 OVER RELIANCE ON NAUTICAL CHARTS. D. Haslam . . . . . I13 MATTHEW FLINDERS AND SHIP MAGNETISM. C. H. CoTTER . . 123 FACTORS CONTRIBUTING TO MARINE CASUALTIES. M. Fuxushima • 135 THE DEVELOPMENT OF MILFORD HAVEN AS A MAJOR PORT. G. DUDLEY . I4I COLLISION AVOIDANCE SYSTEMS AND OPTIMAL TURN MANGUVRES.

A. W. Merz and J. S. Karmarkar . . . . . • . AN EVALUATION TRIAL OF THE NAVIGATION ACCURACY OF THE LIOII.

S. NAGAOKA, E. YOSHIOKA and T. MUTO $. \quad . \quad . \quad . \quad . \quad$. HIGH ACCURACY POSITIONING FOR SUBMARINE PIPELINES. W. F. BROADWOOD

SPHERICAL HYPERBOLAE AND ELLIPSES. H. C. FreIsLeBen NAVIGATION LIGHTS (Forum). B. D. GEORGE
A TABULAR METHOD FOR STAR-SIGHT REDUCTION (Forum). V. NASTRO and $A$. Russo .

A POSITION LINE FROM AN OBJECT OFF THE CHART (Forum). A. B MOODY THE DANGERS OF ROUTING WITHOUT GOOD CONTROL (Forum). J. D. Proctor

STATISTICS OF COLLISIONS AT SEA. A. N. COCKCROFT AUTOMATIC PLOTTING RADARS

I-A COMPARISON OF FACILITIES ON COMPUTER BASED RADARS. K. D. JONES .

Il-RESULTS OF THE STUDY C. S. Perkins $: \quad \cdot \quad \cdot \quad \cdot$

III-COMMENTARY. J. A. BuTT. HE EARLY HISTORY OF GREAT CIRCLE SAILING. C. H. COTTER THE DOVER STRAIT INFORMATION SERVICE: RECENT PROGRESS. R. K. A MARINE ELECTRICAL ANALOG-TYPE DEAD RECKONING COMPUTER. R. N. B. Gatehouse OPTOELECTRONIC DISPLAYS. B. ElLIS . A NOTE ON SHORT-METHOD TABLES (Forum). D. H. SAdler AUTOMATIC RADAR PLOTTERS: THE IMPORTANCE OF THE FUTURE POSITION CONTROL (Forum). F. J. WYLIE . . . . . . 292 
USING A HAND-HELD CALCULATOR FOR SHIP'S POSITION COMPARISON

(Forum). T. R. MEADEN .

ERROR DISTRIBUTION IN NAVIGATION (Forum). O. D. ANDERSON $\quad \cdot \quad$. $\quad 298$

THE CONCEPT OF JACOBRAD (Forum) . . . . . . 301

THE INTER-GOVERNMENTAL MARITIME CONSULTATIVE ORGANIZATION

C. P. SRIVAstava . . . . . . . . . . . 307

TWO CENTURIES OF NAVIGATION

THE ROLE OF TIME IN NAVIGATION. A. Stratron. . . . . . . 317

NAUTICAL ASTRONOMY: PAST, PRESENT AND FUTURE. C. H. COTTER 334

TWO HUNDRED YEARS OF COLLISION REGULATIONS. J. F. KEMP . $\quad \cdot 34^{\mathrm{I}}$

NEW PROSPECTS-THE STRUCTURE OF SEA LANES. R. B. RichardSON . $35^{\circ}$

CONCORDE NAVIGation. B. Calvert and T. C. R. Guest . . $35^{8}$

COLLISION AVOIDANCE MANCEUVRES IN RESTRICTED VISIBILITY. M. J.

BARRATt . . . . . . . . . . . . 364

SYSTEM PROBLEMS IN AIR TRAFFIC CONTROL. S. RATCLIfFE . . $37^{2}$

POLISH CARTOGRAPHY IN THE SIXTEENTH AND SEVENTEENTH CEN-

TURIES. J. WERESZCZYŃSKI • . • . • . . 380

EFFECT ON LOCAL SEA STATES OF WAVE SYSTEMS GENERATED BY

PASSING VESSELS. A DISCUSSION . . . . . . . 385

NAVIGATION AND THE SCHOOLS. E. W. Anderson and W. Weatherston 392

THE MYSTERY OF CAPTAIN LANE'S COMPASS (Forum). W. E. MAY . . 411

SIMPLE SEXTANT CALIBRATION (Forum). D. W. Kerst. . . . $\quad 413$

REPORTING NEAR MISSES AT SEA (Forum). D. NICOLSON . . . 414

SA VING MONEY BY CUTTING CORNERS (Forum). J. D. Proctor. . 418 MATTHEW FLINDERS AND SHIP MAGNETISM (Forum). W. F. J. Mörzer

RECORD

BRUYNS .

REVIEWS 


\section{THE ROYAL INSTITUTE OF NAVIGATION}

THE OBJECT of the Institute is to unite in one body those who are con1 cerned with or who are interested in the science and art of navigation. Membership is not restricted to those who hold professional qualifications, but is open to others who wish to further the aims of the Institute.

By coordinating the knowledge and achievements of marine and air navigators, scientists and those associated with the development and production of navigational equipment, the work of the Institute is directed towards raising the standard of navigation. In the field of education it is the aim of the Institute to bring practical navigators into contact with teachers and research workers to increase a common appreciation of the issues involved. It is an object of the Institute to encourage research in equipment and methods; through its publications it gives a wide circulation to original work on navigation so that new developments and suggestions can be appreciated by those most directly concerned with them.

The activities of the Institute include the holding of monthly meetings to discuss specific problems, the publication of a Journal and of other works concerned with different aspects of navigation, and such other activities as the Council may deem necessary to promote knowledge in navigation and its associated sciences.

The Journal of Navigation is issued free each quarter to all members and contains a full account of the Institute's proceedings. It prints the papers which are presented at meetings, together with their ensuing discussion, and other original papers contributing to the science of navigation. It also contains a record of current navigational work, reviews of important books, and general papers of interest to navigators and those with similar interests.

The work of the Institute is coordinated with that of similar societies abroad, whose proceedings are available to members.

Membership. There are five classes of membership of the Institute :

(1) HONORARY MEMBERs, who shall be distinguished persons upon whom the Council may see fit to confer an honorary distinction.

(2) Fellows, who shall be members, of at least three years' standing who, in the opinion of the Council, have made a contribution of value to navigation.

(3) MEMBERs, who shall be persons over twenty-one years of age who can satisfy the Council of their interest in navigation.

(4) STUDENT MEMBERs, who shall be persons under twenty-five years of age studying with a view to making navigation, or an allied interest, their career.

(5) CORPORATE MEMBERs, who shall be companies, universities, navigation schools, government departments and other organizations, here and abroad, who are directly or indirectly interested in the science of navigation. Corporate Members are entitled to send representatives to all Institute meetings and to receive six copies of the Journal, and other publications. They are encouraged to take an active part in the Institute's work. Application should be by letter addressed to the Director.

Subscriptions. Annual subscriptions to the Institute are payable in advance as follows:

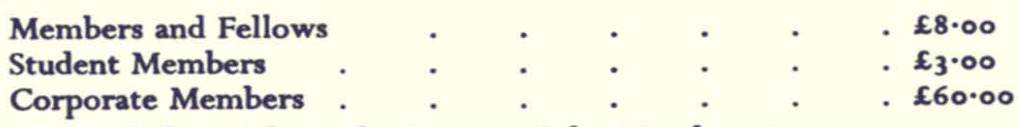

The Institute's financial year begins on I July. Members in any category who are elected after I January in any year are only due for one half of their subscription until I July, when the full subscription for the next year becomes due. 